\title{
ANALISIS BAKTERI E. COLI MINUMAN ES DAWET DI KABUPATEN KUDUS
}

\author{
David Laksamana Caesar ${ }^{1}$, Umi Rohmah ${ }^{2}$
}

${ }^{1,2}$ Prodi S1 Kesehatan Masyarakat, STIKES Cendekia Utama Kudus

\begin{tabular}{ll}
\hline Article Info & ABSTRACT \\
\hline Article history: & The coverage of drinking water quality inspection in \\
Received Mei 14,2021 & Central Java has only reached 82.1\%. One type of \\
Revised Mei 17, 2021 & drinking water that is often consumed by the public is \\
Revised Mei 25, 2021 & dawet ice. Dawet ice can be contaminated by pathogenic \\
Accepted Mei 28,2021 & bacteria, one of which is Escherichia coli (E. coli). \\
\hline Keywords: & Contamination can occur through water used to process \\
E. Coli & coconut milk or from water used to make ice. In addition, \\
Es Dawet & contamination can occur during the processing or \\
& distribution process of dawet ice with. This study aims to \\
& determine the presence of E. coli bacteria in dawet ice \\
& drinks. This type of research uses quantitative descriptive \\
& analysis instrument with the Plate Count Agar (PCA) \\
& method. Samples taken amounted to 30 samples in the \\
& area of Kudus Regency. The results showed that the \\
presence of E. coli bacteria in dawet ice samples sold in \\
Kudus Regency. There are still many dawet ice in Kudus \\
Regency which contain E.coli bacteria, namely 83.4\%. \\
This is because respondents do not pay attention to \\
personal hygiene and sanitation.
\end{tabular}

Corresponding Author:

David Laksamana Caesar

Prodi S1 Kesehatan Masyarakat, STIKES Cendekia Utama Kudus Indonesia

Email: caesar.david77@gmail.com

Journal homepage: https://journal.lppm-unasman.ac.id/index.php/jikm/index 


\section{PENDAHULUAN}

Minuman es dawet adalah minuman yang berbahan dasar tepung kanji, santan dan gula merah ini disajikan dengan es batu sehingga dapat mengenyangkan sekaligus menghilangkan dahaga. Umumnya es dawet dijual oleh pedagang keliling sehingga mudah diperoleh oleh konsumen. Es dawet dapat terkontaminasi oleh bakteri patogen melalui air yang digunakan untuk memproses santan atau dari air yang digunakan untuk membuat es. Selain itu,kontaminasi dapat terjadi selama proses pengolahan atau proses distribusi es dawet. Tangan para pekerja pun dapat menyebabkan cemaran karena kurangnya praktik cuci tangan [1].

Hasil dari penelitian es dawet di bandar lampung yang dilakukan oleh Budiono dkk dalam [2] ada lima sampel yang dianalisis dan tidak memenuhi syarat semua, persentase yang diperoleh dari penelitian tersebut $100 \%$ mengandung bakteri coliform, namun dalam jumlah yang berbeda. Hal ini disebabkan oleh beberapa faktor, yaitu bahan yang digunakan dan peralatan untuk mengelola es dawet tersebut.

Penelitian lain yang dilakukan oleh Puput dan David (2017) pada rumah makan di Terminal Penumpang Pelabuhan Tanjung Emas Semarang diketahui 100\% sampel air bersih pada rumah makan tersebut mengandung bakteri E.Coli. Semua sampel dalam penelitian ini melebihi nilai ambang batas yang ditetapkan dalam Peraturan Menteri Kesehatan No. 416/Menkes/Per/IX/1990 [3].

Menurut Peraturan Menteri Kesehatan Republik Indonesia Nomor 492/Menkes/Per/IV/2010 tentang Persyaratan Kualitas Air Minum parameter mikrobiologi utama yang menentukan kualitas air minum adalah keberadaan E. Coli dan Total Bakteri Koliform dengan kadar maksimum yang diperbolehkan dalam peraturan tersebut adalah nol.[4] Penyebab keracunan makanan menurut Rien dkk [5] adalah adanya cemaran bakteri patogen. Terjadinya keracunan ditandai dengan adanya gejala diare. Jika diare terjadi dalam jangka yang panjang akan dapat menyebabkan kematian. Kasus keracunan terjadi karena penerapan sanitasi lingkungan pengolahan yang masih kurang memadai. Cemaran yang dapat menyebabkan penyakit adalah cemaran mikrobiologi seperti Eschericia coli, Staphylococcus aureus atau bakteri coliform.

Tahun 2018 desa yang terjadi kejadian luar biasa (KLB) di Provinsi Jawa Tengah terus mengalami peningkatan yaitu dari 100 desa/kelurahan pada tahun 2017 menjadi 186 desa/kelurahan. Dari 186 desa/kelurahan mengalami kejadian luar biasa, seluruhnya atau 100 persen ditangani secara cepat (kurang dari 24 jam). Pada tahun 2018, frekuensi tertinggi adalah KLB Keracunan makanan yang terjadi sebanyak 74 kali di 69 kecamatan dan 73 desa/kelurahan. [6].

Berdasarkan hasil observasi yang dilakukan di beberapa pasar dan lokasi pedagang es dawet di Kabupaten Kudus, diketahui terdapat beberapa penjual yang belum menerapkan higiene sanitasi dan hygiene personal dengan baik. Hal ini dapat meningkatkan risiko pencemeran bakteri patogen seperti bakteri E.coli pada minuman es cendol yang dijual. Selain itu, kualitas bahan-bahan yang digunakan untuk membuat es dawet seperti es batu juga berisiko meningkatkan potensi cemaran bakteri E.Coli.

\section{METODE PENELITIAN}

Jenis penelitian ini merupakan penelitian deskriptif kuantitatif yaitu penelitian untuk melihat gambaran fenomena yang terjadi di dalam suatu populasi tertentu. Metode penelitian ini menggunakan instrument penelitian, analisis data bersifat kuantitatif dengan 
rancangan survey cross sectional yaitu suatu penelitian untuk mempelajari dinamika korelasi antara faktor-faktor risiko dengan efek, dengan cara pendekatan, observasi atau pengumpulan data sekaligus pada suatu saat (point time approach).

Penelitian ini dilakukan di Pasar Tradisional dan Pedagang Kaki Lima yang menyediakan es dawet di Kabupaten Kudus. Pemilihan tempat di pasar tadisional dan rumah makan di Kabupaten Kudus dengan pertimbangan di Kabupaten Kudus belum ada yang meneliti kadar E.coli pada es dawet. Selain itu, di Kabupaten Kudus juga terkenal dengan es dawet Pasar Kliwon. Populasi dalam penelitian ini adalah seluruh pedagang di pasar dan pedagang kaki lima pinggir jalan di Kabupaten Kudus yang menyediakan es dawet. Sampel dalam penelitian ini sejumlah 30 sampel es dawet.

Setelah sampel terkumpul kemudian dilanjutkan dengan pemeriksaan mikrobiologi kandungan E. Coli pada es dawet yang dilakukan di Laboratorium Mirobiologi Program Studi Farmasi Sekolah Tinggi Ilmu Kesehatan Cendekia Utama Kudus. Instumen penelitian ini terdiri 1) Alat: tabung reaksi, baker glass, erlenmeyer, timbangan analitik, autoklaf, inkubator, batang pengaduk, cawan petri, pembakar bunsen/ laminar air flow (laf), oven, botol berwarna gelap dan 2) Bahan: sampel minuman es dawet sejumlah 30 sampel, media endo agar, aquades steril, alumunium foil.

Analisa data penelitian ini menggunakan analisis univariat dilakukan terhadap tiap variable dari hasil penelitian, analisis ini dilakukan untuk mendiskripsikan serta menjelaskan hasil pengolahan data dalam bentuk table deskripsi dan frekuensi masingmasing variable [7].

\section{HASIL DAN PEMBAHASAN}

\subsection{Hasil}

Penelitian dilakukan pada 30 responden penjual es cendol di pasar tradisional dan pedagang kaki lima di wilayah Kabupaten Kudus. Berlokasi di 5 kecamatan yaitu Kecamatan Jekulo 10 responden, Kecamatan Bae 3 responden, Kecamatan Kota Kudus 6 responden, Kecamatan Jati 6 responden, dan Kecamatan Mejobo 5 responden. Berdasarkan hasil analisis laboratorium yang telah dilakukan pada tanggal 14-15 Juli 2020, jika berwarna merah menandakan adanya bakteri E.coli dan jika tidak berwarna menandakan tidak adanya bakteri E.coli. Diperoleh hasil sebagai berikut:

Tabel 1. Hasil Analisa Laboratorium Kandungan E.Coli Es Dawet

\begin{tabular}{lcc}
\hline \multicolumn{1}{c}{ Kandungan E. Coli } & Frekuensi & Prosentase $(\%)$ \\
\hline Memenuhi Syarat & 5 & 16,7 \\
\hline Tidak Memenuhi & 25 & 83,3 \\
Syarat & & \\
\hline Total & 30 & 100,0 \\
\hline
\end{tabular}

Berdasarkan hasil analisa laboratorium di atas diketahui 16,7\% sampel es cendol negative E.Coli atau memenuhi syarat Kesehatan, sedangkan 83,3\% lainnya positif E.Coli atau tidak memenuhi syarat Kesehatan. Sampel yang positif E. Coli terdiri dari sampel nomor 7, 9, 11, 15, dan 24. Sedangkan sampel lain negative E.Coli. 


\subsection{Pembahasan}

Hasil penelitian menunjukan Sebagian besar sampel es dawet positif terkontaminasi bakteri E.Coli. Secara umum sampel yang positif ini berada pada lokasi pasar tradisional di Kabupaten Kudus. Kondisi pasar yang tidak terjaga kebersihannya menyebabkan risiko perkembangan bakteri pathogen semakin tinggi, dan semakin meningkatkan risiko kontaminasi pada makanan atau minuman yang dijajakan di sekitar wilayah pasar tersebut, salah satunya adalah es dawet.

Selain factor kebersihan pasar, kebersihan personal dari pedagang juga dapat meningkatkan kontaminasi pada makanan dan minuman yang dijual.. Hal ini sesuai dengan penelitian yang dilakukan oleh Rahmayani (2019) yaitu peralatan yang digunakan untuk mengolah makanan jajanan harus sesuai dengan peruntukannya dan memenuhi persyaratan higiene sanitasi. Peralatan yang sudah dipakai harus dicuci dengan air bersih dan sabun lalu dikeringkan dengan alat pengering/lap yang bersih kemudian disimpan di tempat yang bebas pencemaran. Air yang digunakan dalam pengolahan makanan jajanan juga harus memenuhi standar dan persyaratan higiene sanitasi yang berlaku bagi air bersih atau air minum. Air bersih yang digunakan untuk membuat minuman harus dimasak sampai mendidih.[8]

Factor lain yang mungkin berisiko meningkatkan kandungan E.Coli pada es dawet adalah kualitas es dan bahan-bahan yang digunakan untuk membuat es dawet tersebut. Hal ini sejalan dengan penelitian yang dilakukan oleh Budiono, dkk (2018) yaitu lima sampel yang diteliti tidak memenuhi syarat atau $100 \%$ sampel mengandung bakteri E.Coli. Hal ini disebabkan oleh beberapa faktor, yaitu bahan yang digunakan dan peralatan untuk mengelola es dawet tersebut. Bahan-bahan yang menyebabkan masih adanya bakteri coliform (E.coli) seperti air yang digunakan untuk membuat es kurang matang atau air yang digunakan untuk membuat es tidak dimasak terlebih dahulu (menggunakan air mentah), air yang digunakan untuk memeras santan adalah air mentah dan pemasakan santan tidak matang, serta bahan lain yang dimasak dan dicuci menggunakan air seperti dawet, cendol, dan buah yang dicampur ke dalam es dawet tersebut. Faktor lain yaitu peralatan yang digunakan, air yang digunakan untuk mencuci peralatan tersebut digunakan secara berulang bahkan tempat pembuatan yang kurang higienis, adanya peresapan air limbah dan tangan produsen yang tidak bersih.[2]

\section{KESIMPULAN}

Sampel es yang diteliti berjumlah 30 sampel dengan 5 sampel negatif bakteri E.coli atau 16,7\% dan 15 sampel positif bakteri E.coli atau 83,3\% Penyebab banyaknya sampel yang positif bakteri E.coli. Masih banyaknya sampel yang mengandung bakteri E.coli di

Kabupaten Kudus dikarenakan responden masih kurang memperhatikan kebersihan lingkungan tempat jualan dan terutama higiene personal responden selaku sebagai penjamah 


\section{DAFTAR RUJUKAN}

[1] Husna, H. (2018). Identifikasi Escherichia coli pada Es Dawet di Kota Banda Aceh. Serambi Saintia: Jurnal Sains dan Aplikasi, 6(1). 7-15.

[2] Budiono, I. J., Primadiamanti, A., \& Feladita, N. (2018). Uji Cemaran Bakteri Coliform Pada Minuman Es Dawet Yang Beredar Di Kecamatan Kedaton Bandar Lampung Dengan Metode Most Probable Number (Mpn). Jurnal Farmasi Malahayati, 1(1), 37-43.

[3] Kadarsih, P., \& Caesar, D. L. (2017). Total Coliform Air Bersih pada Rumah Makan Terminal Penumpang Pelabuhan Tanjung Emas Semarang. Jurnal Keperawatan dan Kesehatan Masyarakat Cendekia Utama, 6(1). 31-36.

[4] Menteri Kesehatan RI. (2010). Peraturan Menteri Kesehatan Republik Indonesia Nomor 492/Menkes/Per/IV/2010 tentang Persyaratan Kualitas Air Minum. Kementeri Kesehatan : Jakarta.

[5] Putri, A. M., \& Kurnia, P. (2018). Identifikasi Keberadaan Bakteri Coliform Dan Total Mikroba Dalam Es Dung-Dung Di Sekitar Kampus Universitas Muhammadiyah Surakarta [Identification Of Coliform Bacteria And The Total Mikrobes In Dung-Dung Ice Around Universitas Muhammadiyah Surakarta Campus]. Media Gizi Indonesia, 13(1), 41-48.

[6] Kemenkes RI. Profil Kesehatan Indonesia tahun 2017. Jakarta : Kemenkes RI: 2018.

[7] Sugiyono.2016. Metode Penelitian Kuantitatif Kualitatif dan R\&D. Alfabeta: Bandung.

[8] Rahmayani, R. D., \& Simatupang, M. M. (2019). Analisis Pengaruh Higiene Penjamah Dan Sanitasi Makanan Terhadap Kontaminasi E. Coli Pada Jajanan Sekolah. JUKMAS: Jurnal Untuk Masyarakat Sehat, 3(2), 164-178. 